\title{
PERAN ORGANISASI GERAKAN MAHASISWA NASIONAL INDONESIA DALAM MENTRANSFORMASIKAN NILAI-NILAI PANCASILA DI UNIVERSITAS MUHAMMADIYAH MALANG
}

\author{
Arif Prasetyo Wibowo ${ }^{1^{*}}$, Yusa Djuyandi², Leo Agustino ${ }^{3}$ \\ ${ }^{1}$ FKIP Universitas Muhammadiyah Malang, Indonesia \\ 1Email: arifpwibowo@umm.ac.id \\ ${ }^{2}$ FISIP, Universitas Padjadjaran, Indonesia \\ ${ }^{2}$ Email: f_yusa@yahoo.com \\ ${ }^{3}$ FISIP, Universitas Sultan Ageng Tirtayasa Serang, Indonesia \\ 3Email: leoagustino@gmail.com
}

\begin{abstract}
ABSTRAK
Tujuan dalam penelitian ini adalah untuk mengetahui dan menganalisis peran Organisasi Gerakan Mahasiswa Nasional Indonesia di Universitas Muhammadiyah Malang dalam mentransformasikan nilai-nilai Pancasila kepada para kadernya. Metode yang digunakan dalam penelitian ini adalah deskriptif kualitatif. Dengan temuan penelitian peran organisasi Dewan Pimpinan Komisariat Gerakan Mahasiswa Nasional Indonesia Universitas Muhammadiyah Malang dalam mentrasformasikan nilai-nilai Pancasila dilakukan dengan bentuk Program Kerja disetiap periode kepengurusan organisasi yang dapat dilihat melalui lima indikator dalam teori peran, yakni aksi, patokan, penilaian, paparan, dan sanksi.
\end{abstract}

Kata Kunci: Organisasi Mahasiswa; Transformasi Nilai-Nilai Pancasila.

\begin{abstract}
The purpose of this research is to see and analyze the role of the Gerakan Mahasiswa Nasional Indonesia at the University of Muhammadiyah Malang in transforming the values of Pancasila to its cadres. This study applies descriptive-qualitative design. The results of this study showed that the role of Board of Commissioners of the Indonesian National Movement in Universitas Muhammadiyah Malang in transforming Pancasila moral values to organizational work program in management period could be seen through five indicators, namely action, benchmark, assessment, change, consideration, and punishment.
\end{abstract}

Keywords: Students' Organization; Transformation of Pancasila Values

\section{PENDAHULUAN}

Pancasila sebagai ideologi, pandangan hidup, dan dasar negara Republik Indonesia dewasa ini mendapatkan tantangan. Hasil survei yang dilakukan oleh Lingkaran Survei Indonesia Denny J.A. menyebutkan telah terjadi penurunan kepercayaan publik terhadap ideologi negara, hal ini dapat di lihat pada tahun 2005 publik yang proPancasila angkanya mencapai $85,2 \%$, tahun 2010 angkanya menjadi $79,4 \%$, tahun 2015 angkanya menjadi 79,4\% dan di tahun 2018 menjadi 75,3\%. Dalam waktu 13 tahun, publik yang pro-Pancasila mengalami penurunan sebanyak $10 \%$. Sedangkan publik yang pro-NKRI bersyariah islam mengalami kenaikan sebanyak 9\% (Hidayat, 2018).

Lebih lanjut dalam survei terbaru yang dilakukan oleh Cyrus Network pada 22 sampai 28 Juli 2019 dengan melibatkan 1.230 responden di 34 provinsi di Indonesia menunjukan hanya 70,3 persen responden yang beragama Islam setuju dan menerima Pancasila sebagai dasar negara. Sisanya 4,7 persen responden yang terang-terangan mendukung terbentuknya khilafah, kemudian 13 persen responden menyatakan Indonesia harus berlandaskan syariat Islam karena merasa Islam adalah agama mayoritas. Managing Director 
Cyrus Network Eko Dafid Afianto mengemukakan, hasil survei tersebut perlu mendapatkan perhatian serius dan menjadi pekerjaan rumah bersama dalam menanggapi jumlah yang cukup besar terkait masih adanya sikap menolak ideologi negara tersebut (CNN Indonesia, 2019).

Sejak rezim Orde Baru tumbang muncul phobia terhadap Pancasila, Dasar Negara itu untuk sesaat dilupakan, dipinggirkan bahkan ditinggalkan karena Pancasila selalu diidentikan dengan rezim orde baru-sebuah rezim yang tumbang akibat reformasi. Tampaknya ada semacam trauma mendalam terhadap perlakuan eksesif terhadap Pancasila. Dasar Negara itu berubah menjadi ideologi tunggal dan satu-satunya sumber nilai serta kebenaran. Negara menjadi maha tahu mana yang benar dan mana yang salah. Nilai-nilai itu ditanam di benak masyarakat melalui indoktrinasi (Ali, 2009).

Phobia terhadap Pancasila tersebut membuat masyarakat melakukan pencarian jalan keluar untuk menyeleseikan masalah dalam menghadapi persoalan kehidupan bermasyarakat, berbangsa, dan bernegara. Namun pencarian tersebut mengarah kepada melupakan Pancasila sebagai pandangan hidup serta ideologi negara dan memilih melihat ideologi alternatif lain dalam menyeleseikan berbagai permasalahan yang di hadapi. Hal tersebut menurut Prof. B. J. Habibie (dalam Siregar, 2012) dalam peringatan Pidato Bung Karno 1 Juni 2011 menyatakan Pancasila seolah tenggelam dalam pusaran sejarah masa lalu yang tidak lagi relevan untuk disertakan dalam dialektika refomasi sekarang ini. Pancasila seolah hilang dari memori kolektif bangsa. Pancasila semakin jarang diucapkan, dikutip, dibahas, dan apalagi diterapkan, baik dalam konteks ketatanegaraan, kebangsaan maupun kemasyarakatan. Pancasila seperti tersandar di sebuah lorong sunyi, justru di tengah denyut kehidupan berpolitik.
Ditambah lagi pendidikan politik yang seharusnya dilakukan oleh partai politik kepada masyarakat sebagai usaha sosialisasi politik terhadap ideologi Pancasila sendiri nyatanya tenggelam dalam hiruk pikuk perebutan kekuasaan (Saputro, 2015). Padahal sudah diatur dalam Undang-Undang Nomor 2 Tahun 2011 tentang Perubahan Atas UndangUndang Nomor 2 Tahun 2008 tentang Partai Politik dimana Partai Politik menerima bantuan keuangan dari APBN/APBD untuk melakukan kegiatan pendidikan politik. Akan tetapi karena pemahaman mengenai pendidikan politik sangat lentur dan tidak ada pertanggungjawaban untuk substansinya maka efektivitas program tersebut belum dapat teruji (Wibowo, 2020).

Kehidupan berpolitik bangsa Indonesia yang diwakili oleh tata kelola partai politik masih jauh dari keadaan yang ideal. Pertama, partai politik yang menjadi salah satu pilar utama kehidupan berdemokrasi dan berpolitik masih harus terus berproses dalam menjalankan amanat sebagai penyalur aspirasi masyarakat. Kedua, partai politik belum menjadikan pendidikan politik sebagai sorotan utama (Wibowo \& Wahono, 2017).

Sebagai das sollen, usaha-usaha menemukan stelsel dan mekanisme demokrasi yang cocok bagi masyarakat Indonesia sangat dihargai. Namun, pada tataran das sein bukan sesuatu yang mudah dijelmakan. Hal itu disebabkan perpaduanperpaduan konseptual ternyata tidak disertai dengan penjabaran mengenai rule of the game yang juga menggambarkan perpaduan tersebut. Selain itu, tingkah laku politik turut memberikan kontribusi yang serius. Akibatnya, para pelaku demokrasi bebas menciptakan rule of the game menurut paham dan pengetahuan yang memengaruhi diri mereka serta keinginankeinginan politik yang hendak dicapai (Manan \& Harijanti, 2014).

Mahasiswa sebagai pemuda kelompok kelas menengah berpendidikan sejatinya 
merupakan pemegang tongkat estafeta kepemimpinan bangsa dan negara di masa yang akan datang dalam merespon tantangan tersebut. Sejarah mencatat momentum Sumpah Pemuda yang terjadi pada 28 Oktober 1928, Penculikan tokoh nasional pada 16 Agustus 1945 ke Rengas Dengklok, demonstrasi yang dilakukan oleh mahasiswa pada masa orde lama yang di gawangi oleh mahasiswa sebagai kelompok pemuda kelas menengah berpendidikan dengan membentuk Kesatuan Aksi Mahasiswa Indonesia (KAMI), dan gerakan reformasi 21 Mei 1998 yang di pelopori oleh mahasiswa sebagai pemuda kelompok kelas menengah berpendidikan untuk menumbangkan rezim orde baru yang tiran merupakan berbagaimacam contoh nyata peran pemuda dalam melalukan perubahan sosial menuju ke arah yang lebih baik pada kehidupan berbangsa dan bernegara.

Akbar (2016) dalam penelitiannya melihat berbagai gerakan yang dilakukan oleh pemuda dengan status sosial sebagai mahasiswa tersebut dapat di kelompokan sebagai komponen masyarakat kelas menengah. Mahasiswa sebagai pemuda kelompok kelas menengah tersebut menjadi berbeda dengan masyarakat awam pada umumnya karena mereka kelompok masyarakat berpendidikan yang sehari-harinya bergelut dengan pencarian kebenaran di dalam kampus. Sehingga ketika mereka melihat kenyataan yang berbeda dalam kehidupan nasionalnya akan menimbulkan kegelisahan tersendiri di kalangan mahasiswa yang kemudian teraktualisasi dalam aksi-aksi protes atau gerakan sosial yang kemudian mendorong perubahan reformatif dalam sistem politik di Indonesia.

Namun sejak gerakan reformasi digulirkan dari kampus-kampus di tanah air, (Taniredja, 2014) dalam menelitiannya menilai mahasiswa nampak berkembang dengan kecenderungan untuk menafikan Pancasila sebagai ideology dalam kehidupan kebangsaan dan kenegaraan kita. Akibatnya proses "colonialization of the mind" di dalam kampus secara tidak disadari menjadi semakin marak dan pendidikan tinggi dalam mentransformasikan ilmu pengetahuannya menjadi "Salah Asuhan". Hal tersebut berlangsung secara terus menerus tanpa hambatan, sehingga menghasilkan para lulusan yang lebih menghayati paradigma ilmu pengetahuan milik budaya bangsa lain daripada ilmu pengetahuan yang berakar dari budaya bangsa sendiri.

Dari hasil penelitian yang dilakukan oleh Zamroni (1990) melihat fenomena tersebut maka tantangan utama organisasi mahasiswa di bidang politik dan pembangunan masyarakat adalah bagaimana kemampuan mahasiswa dalam melakukan pendidikan politik terhadap anggotanya. Pendidikan politik yang dimaksud adalah suatu proses dimana anggota masyarakat menghayati nilai-nilai dan norma-norma suatu sistem politik yang bersumber dari falsafah dan dasar negara masyarakat yang bersangkutan. Proses pendidikan politik tersebut berlangsung tidak hanya melalui pendidikan formal, melainkan juga di keluarga dan masyarakat. Hal ini dapat dikatakan agen pendidikan politik tidak hanya sekolah, melainkan keluarga, dan organisasi-organisasi kemasyarakatan, terutama pemuda.

Berdasarkan data penelitian terdahulu yang dilakukan oleh Wibowo, Sumantri, dan Syaifullah(2016)dijelaskanprogramkerjayang diselenggarakan oleh organisasi mahasiswa intra kampus di Fakultas Pendidikan Ilmu Pengetahuan Sosial, Universitas Pendidikan Indonesia merupakan proses transformasi nilai, dimana dalam setiap kegiatan yang diselenggarakannya terdapat inti nilai dari Pancasila yang ditransformasikan menjadi program kerja. Organisasi mahasiswa intra kampus merupakan mesin transformasi nilai yang baik, karena didalam organisasi mahasiswa insta kampus terdapat bermacammacam pola yang dilakukan dalam 
penyelenggaraan setiap progran kerja yang akan diselenggarakan dan dari setiap pola tersebut merupakan proses yang dilakukan oleh organisasi mahasiswa intra kampus dalam mentransformasi nilai-nilai Pancasila.

Penelitian ini menjadikan Dewan Pengurus Komisariat Gerakan Mahasiswa Nasional Indonesia Universitas Muhammadiyah Malang sebagai subjek, hal tersebut lantaran dalam penelitian yang di lakukan oleh Pratama (2018) menjelaskan peran Organisasi Mahasiswa seperti Dewan Pimpinan Cabang Gerakan Mahasiswa Nasional Indonesia Bandar Lampung (DPC GMNI Bandar Lampung) dalam pembentukan karakter berbasis pada nilai-nilai ideologi Pancasila adalah baik, yakni 57,8\%. Selanjutnya peran organisasi Gerakan Mahasiswa Nasional Indonesia (GMNI) dalam meningkatkan sikap nasionalisme menunjukan angka yang baik, yakni 60\%. Lebih lanjut peran organisasi Gerakan Mahasiswa Nasional Indonesia (GMNI) terhadap pelaksanaan sikap nasionalisme di dalam organisasi adalah baik, yakni 64,4\%.

Adapun kebaharuan yang dilakukan dalam penelitian ini diantaranya adalah untuk mendeskripsikan serta menganalisis secara mendalam bagaimana peran Organisasi Mahasiswa Dewan Pengurus Komisariat Gerakan Mahasiswa Nasional Indonesia Universitas Muhammadiyah Malang dalam mentrasformasikan nilainilai Pancasila kepada para kadernya.

\section{METODE}

Kajian ini menggunakan pendekatan kualitatifdengan jenis studi kasus. Pemilihan pendekatan ini dikarenakan permasalahan yang dikaji pada Dewan Pengurus Komisariat Gerakan Mahasiswa Nasional Indonesia Universitas Muhammadiyah Malang membutuhkan sejumlah data lapangan yang sifatnya kontekstual dan aktual. Selain itu pendekatan kualitatif menyajikan secara langsung hakikat hubungan antara peneliti dengan responden sehingga dapat disimpulkan pendekatan kualitatif memiliki sifat fleksibilitas yang tinggi, artinya memudahkan peneliti untuk menyesuaikan situasi yang berubah-ubah dalam penelitian ini. Data dikumpulkan melalui observasi, wawancara, dan dokumentasi. Teknik analisis data menggunakan analisis interaktif yang dikemukakan oleh Miles dan Huberman.

\section{HASIL DAN PEMBAHASAN}

\section{Aksi Yang Dilakukan Oleh Gerakan Mahasiswa Nasional Indonesia Dalam Mentransformasikan Nilai-Nilai Pancasila Di Universitas Muhammadiyah Malang}

Secara kajian teoritis teori peran dijelaskan oleh Biddle dan Thomas (dalam Suhardono, 1994) dapat menggambarkan peran seorang aktor sesungguhnya berada dalam suatu batasan yang dirancang oleh aktor lain, yang kebetulan samasama berada dalam "penampilan/ unjuk peran" (role performance). Hubungan antara pelaku (actor) dan pasangan laku perannya (role partner) bersifat saling terkait dan saling mengisi; karena dalam konteks sosial, tak satu peran pun dapat berdiri sendiri tanpa yang lain. Dengan ungkapan lain, suatu peran akan memenuhi keberadaanya, jika berada dalam kaitan posisional yang menyertakan dua pelaku peran yang komplementer.

Dari hasil temuan dilapangan diketahui peran organisasi Dewan Pimpinan Komisariat Gerakan Mahasiswa Nasional Indonesia Universitas Muhammadiyah Malang dalam mentrasformasikan nilai-nilai Pancasila dilakukan dengan bentuk Program Kerja disetiap periode kepengurusan organisasi. DPK GMNI UMM dipimpin oleh Komisaris sebagai aktor utama yang bertanggung jawab atas semua program kerja yang dilaksanakannya dalam satu periode kepengurusan. Dalam kepengurusan tersebut terdapat berbagai macam 
bidang yang bertanggung jawab dalam melaksanakan program kerja organisasi dan merupakan pasangan laku peran dari Komisaris. Setiap program kerja yang diselenggarakan diikuti oleh anggota atau terbuka untuk umum.

Lebih lanjut teori peran menurut Biddle dan Thomas (dalam Suhardono, 1994) menjelaskan konsep peran merupakan seperangkat patokan yang membatasi apa perilaku yang mesti dilakukan oleh seseorang, yang menduduki suatu posisi. Matriks Orang-Perilaku: matriks ini terdiri dari suatu "perangkat perilaku" (set of behavior) yang merupakan perpotongan antara "perangkat subyek" (set of subjects) dan "perangkat kelas perilaku" (set of behavioral classes) yang dapat di gambarkan dengan tabel 1 berikut:

Peristilahan untuk pemilihan konsep

Tabel 1. Peristilahan Untuk Pemilihan Konsep Perilaku Baik Perorangan Ataupun Kumpulan Orang

\begin{tabular}{|c|c|c|c|c|}
\hline \multirow{3}{*}{$\begin{array}{c}\text { Pembedaan } \\
\text { Pemilihan } \\
\text { menurut } \\
\text { Perilaku } \\
\end{array}$} & \multicolumn{4}{|c|}{ Orang } \\
\hline & \multicolumn{2}{|c|}{ Perorangan } & \multicolumn{2}{|c|}{ Kumpulan Orang } \\
\hline & Tak Kasat & Kasat Mata & Tak Kasat & Kasat Mata \\
\hline Aksi & Motif Perorang & Kinerja Perorang & Motif Kumpulan Orang & $\begin{array}{l}\text { Kinerja Kumpulan } \\
\text { Orang }\end{array}$ \\
\hline Patokan & Norma Perorang & Tuntutan Perorang & Norma Kumpulan Orang & $\begin{array}{c}\text { Tuntutan Kumpulan } \\
\text { Orang }\end{array}$ \\
\hline Penilaian & Nilai Perorang & Tafsiran Perorang & Nilai Kumpulan Orang & $\begin{array}{l}\text { Tafsiran Kumpulan } \\
\text { Orang }\end{array}$ \\
\hline Paparan & Konsepsi Perorang & Pernyataan Perorang & Konsepsi Kumpulan Orang & $\begin{array}{l}\text { Pernyataan Kumpulan } \\
\text { Orang }\end{array}$ \\
\hline Sanksi & $\begin{array}{c}\text { Sanksi Tak Kasat Mata } \\
\text { Perorang }\end{array}$ & $\begin{array}{c}\text { Sanksi Kasat Mata } \\
\text { Perorang }\end{array}$ & $\begin{array}{c}\text { Sanksi Tak Kasat Mata } \\
\text { Kumpulan Orang }\end{array}$ & $\begin{array}{l}\text { Sanksi Kasat Mata } \\
\text { Kumpulan Orang }\end{array}$ \\
\hline
\end{tabular}

(Sumber: Biddle dan Thomas (dalam Suhardono, 1994)

perilaku kumpulan orang menurut Biddle dan Thomas (dalam Suhardono, 1994) dapat di bagi menjadi lima pembeda pemilihan menurut perilakunya. Pertama, aksi adalah suatu perilaku yang dibedakan atas pernah tidaknya hal tersebut dipelajari sebelumnya, keterarahannya pada tujuan, serta penampakan dari aspek kehendaknya (bersifat volutional). Istilah ini lebih umum dipakai untuk menunjuk suatu "perilaku kasat mata" (overt behavior), yang dalam kaitannya dengan teori peran lebih tepat dikatakan sebagai "penampilan/ unjuk peran" (role performance) atau "perwujudan peran" (role enactment), "perilaku peran" (role behavior) atau "pola perilaku" (behavior pattern). Istilah "unjuk peran" pada umumnya menunjuk pada penampilan dari kategori "person" tertentu, atau konteks institusi tertentu, misalnya: "unjuk peran pemimpin" atau "unjuk kerja pelajar".

Bila merujuk kepada teori peran yang diungkapkan oleh Biddle dan Thomas (dalam Suhardono, 1994) adapun aksi kasat mata kumpulan orang dalam organisasi ini merupakan program kerja yang telah dilaksanakan oleh Dewan Pimpinan Komisariat Gerakan Mahasiswa Nasional Indonesia Universitas Muhammadiyah Malang pada masa kepengurusan 20182019 diantaranya adalah Pekan Penerimaan Anggota Baru, Kaderisasi Tingkat Dasar, diskusi rutin mingguan mengenai ideologi tentang Marhaenisme dan Pancasila 1 Juni ajaran Bung Karno, keorganisasian, serta memperkenalkan biografi tokoh bangsa yakni Bung Karno, kajian dan diskusi di hari-hari besar dengan mengundang organisasi eksternal dan organisasi internal kampus, penyikapan terhadap isu-isu kontemporer yang berkembang didalam kampus maupun luar kampus, serta yang terakhir silaturahmi antar anggota dan alumni Dewan Pimpinan Komisariat Gerakan Mahasiswa Nasional Indonesia Universitas Muhammadiyah Malang yang diselenggarakan setahun sekali.

Yinger (dalam Suhardono, 1994) paham yang digunakan untuk mengkaji 
teori peran ini adalah paham strukturalis dan paham interaksionis. Paham strukturalis lebih mengaitkan antara peran-peran sebagai unit kultural serta mengacu ke perangkat hak dan kewajiban, yang secara normatif telah dicanangkan oleh sistem budaya. Sistem budaya tersebut menyediakan suatu sistem posisional, yang menunjuk pada suatu unit dari struktur sosial, yaitu "... location in a system of social relationship". Pada intinya, konsep struktur menonjolkan suatu konotasi pasif-statis, baik pada aspek permanensi, maupun aspek saling-kait antara posisi satu dengan yang lainnya.

Bila melihat Anggaran Dasar dan Anggaran Rumah Tangga Gerakan Mahasiswa Nasional Indonesia yang di tetapkan dalam Kongres Trisaksi GMNI Ke-XX (2017) setiap Dewan Pimpinan Komisariat memiliki tugas wewenang menghimpun calon anggota, menarik uang pangkal, dan iuran serta pengadaan tentang kebijakan nasional organisasi kepada seluruh anggota ditingkat basis, melaksanakan Pekan Penerimaan Anggota Baru (PPAB) dan Kaderisasi Tingkat Dasar (KTD), dan melaksanakan pertemuan-pertemuan antar Anggota Dewan Pengurus Komisariat.

Lebih lanjut motif tak kasat mata dari orgnanisasi Dewan Pengurus Komisariat Gerakan Mahasiswa Nasional Indonesia Universitas Muhammadiyah Malang sebagai kumpulan orang dalam teori peran yang diutarakan oleh Biddle dan Thomas (dalam Suhardono, 1994) diperiode 2018-2019 diketahui memiliki Visi "memperjuangkan kembali GMNI Komisariat Universitas Muhammadiyah Malang sebagai lokomotif Gerakan Mahasiswa yang menjunjung tinggi ideologi Marhaenisme". Dengan Misi melaksanakan ideologisasi secara massif, terstruktur, dan sistematis, serta Doktrinasi ideologis terbangun secara kontinyu dan berkesinambungan dalam setiap kegiatan diskusi kader.

Dengan visi dan misi tersebut maka
Bidang Kaderisasi sebagai pasangan laku peran (role partner) dalam kepengurusan Dewan Pimpinan Komisariat Gerakan Mahasiswa Nasional Indonesia memiliki peranan lebih untuk merealisasikan setiap misi yang dimiliki oleh organisasi sebagai aksi dari kinerja kumpulan orang, yang dalam periode kepengurusan 2018-2019 dituangkan melalui kegiatan diskusi rutin mingguan mengenai ideologi tentang Marhaenisme, Pancasila 1 Juni ajaran Bung Karno, keorganisasian, serta memperkenalkan biografi tokoh bangsa yakni Bung Karno. Dengan program wajib melaksanakan Pekan Penerimaan Anggota Baru (PPAB) dan Kaderisasi Tingkat Dasar (KTD).

Menurut (Alfian, 1986b) kegiatan kajian dalam sebuah organisasi dapat di katakan sebagai kegiatan pendidikan politik yang dapat dibagi menjadi dua bagian; pertama, pendidikan politik dalam arti kata yang longgar adalah bagian langsung dari kehidupan masyarakat sehari-hari. disenangi atau tidak, diketahui atau tidak, disadari atau tidak, hal itu dialami oleh anggota-anggota masyarakat, baik penguasa ataupun orang awam. Kedua, pendidikan politik dalam arti yang lebih ketat dapat diartikan sebagai usaha yang sadar untuk mengubah proses sosialisasi politik masyarakat sehingga mereka menghayati dan memahami betul nilainilai yang terkandung dalam suatu sistem politik yang ideal yang hendak dibangun.

\section{Patokan Yang Dilakukan Oleh Gerakan Mahasiswa Nasional Indonesia Dalam Mentransformasikan Nilai-Nilai Pancasila Di Universitas Muhammadiyah Malang}

Peristilahan yang kedua untuk pemilihan konsep perilaku kumpulan orang menurut Biddle dan Thomas (dalam Suhardono, 1994) adalah patokan. patokan (Prescription), istilah “peran" sudah dengan sendirinya diperlakukan secara preskriptif (sebagai patokan), artinya menunjuk kepada perilaku yang mengandung 
"keharusan" (oughtness, shouldness) untuk dibawakan. Sejajar dengan istilah patokan ini terdapat pula istilah "pengharapan" (expectation), "pengharapan peran" (role expectation), "bakuan" (standart), "norma" (norm), dan "kaidah" (rules). Patokan yang dianut secara tak kasat mata (covert) disebut sebagai norma, sedang yang dianut secara kasat mata adalah "tuntutan" (demand). Tuntutan lebih lazim diterapkan pada lingkungan politis, pekerjaan, pendidikan dan situasi kelompok kecil. Pada hakikatnya, setiap kehidupan sosial tak dapat bebas dari patokan ini.

Visi dan Misi, serta program kerja yang diselenggarakan oleh Dewan Pengurus Komisariat Gerakan Mahasiswa Nasional Indonesia Universitas Muhammadiyah Malang merupakan patokan yang menjadi tuntutan kumpulan orang yang dilakukan oleh organisasi tersebut. Hal tersebut karena mengacu pada Dewan Pimpinan Komisariat Gerakan Mahasiswa Nasional Indonesia Universitas Muhammadiyah yang secara terstruktur, massif, dan sistematis telah melakukanusaha sosialisasipolitik terhadap para anggotanya agar mampu menghayati dan memahami nilai-nilai yang terkandung didalam ideologi organisasinya, yakni Marhaenisme. Sehingga diharapkan para anggota dapat memahami sistem politik ideal yang hendak di bangunnya. Upaya terstruktur, massif, dan sistematis dalam melakukan sosialisasi politik terhadap para kader merupakan norma dari patokan yang dilakukan oleh kumpulan orang menurut teori peran Biddle dan Thomas (dalam Suhardono, 1994).

Penilaian Yang Dilakukan Oleh Gerakan Mahasiswa Nasional Indonesia Dalam Mentransformasikan Nilai-Nilai Pancasila Di Universitas Muhammadiyah Malang

Peristilahan yang ketiga untuk pemilihan konsep perilaku kumpulan orang menurut Biddle dan Thomas (dalam Suhardono, 1994) adalah penilaian (evaluation), istilah yang dikaitkan dengan "penilaian" adalah "pilihan" (preference), "nilai", kecondongan (affect), dan penghargaan (esteem). Perilaku tak kasat mata yang menyertakan penilaian, dinamakan nilai; sedang pada perilaku kasat mata, dinamakan "taksiran” (assessment).

Dalam Kongres Trisaksi GMNI KeXX (2017) disebutkan sebagai organisasi gerakan perjuangan, Gerakan Mahasiswa Nasional Indonesia memiliki Azas dan Doktrin Perjuangan, yang menjadi landasan serta penuntun arah perjuangan Gerakan Mahasiswa Nasional Indonesia. Azas dan Doktrin Perjuangan Gerakan Mahasiswa Nasional Indonesia ini adalah Pancasila yang didalamnya setiap anggota Gerakan Mahasiswa Nasional Indonesia diwajibkan membaca dan melakukan kajian mengenai Pidato Bung Karno 1 Juni 1945, Undang-Undang Dasar Negara Republik Indonesia Tahun 1945, Marhaenisme ajaran Bung Karno yakni Sosio-Nasionalisme, Sosio-Demokrasi, dan Ketuhanan Yang Berkebudayaan, serta PANCALOGI GMNI.

Merujuk terhadap teori peran yang diutarakan oleh Biddle dan Thomas (dalam Suhardono, 1994) tersebut maka Azas dan Doktrin Perjuangan Gerakan Mahasiswa Nasional Indonesia dengan mewajibkan seluruh anggota membaca diwajibkan membaca dan melakukan kajian mengenai Pidato Bung Karno 1 Juni 1945, UndangUndang Dasar Negara Republik Indonesia Tahun 1945, Marhaenisme ajaran Bung Karno yakni Sosio-Nasionalisme, Sosio-Demokrasi, dan Ketuhanan Yang Berkebudayaan, serta PANCALOGI GMNI merupakan tafsiran Dewan Pimpinan Komisariat Gerakan Mahasiswa Nasional Indonesia terhadap ideologi organisasinyayang di transformasikan melalui program kerja dalam setiap periode kepengurusannya. 
Paparan Yang Dilakukan Oleh Gerakan Mahasiswa Nasional Indonesia Dalam Mentransformasikan Nilai-Nilai Pancasila Di Universitas Muhammadiyah Malang

Selanjutnya peristilahan yang keempat untuk pemilihan konsep perilaku kumpulan orang menurut teori peran Biddle dan Thomas (dalam Suhardono, 1994) adalah paparan (Description), suatu perilaku dikatakan bersifat deskriptif, kalau orang yang menghadirkan kejadian perilaku tersebut, baik berwujud proses atau fenomenannya tidak mengandung aspek evaluatif atau afektif. Paparan tak kasat mata diistilahkan dengan "pernyataan" (statement).

Berdasarkan hasil temuan dilapangan, pelaksanaan setiap program kerja yang dilakukan oleh Dewan Pimpinan Komisariat Gerakan Mahasiswa Nasional Indonesia Universitas Muhammadiyah mengacu kepada Anggaran Dasar dan Anggaran Rumah Tangga Gerakan Mahasiswa Nasional Indonesia. Dimana setiap Dewan Pimpinan Komisariat memiliki tugas wewenang melaksanakan Pekan Penerimaan Anggota Baru (PPAB) dan Kaderisasi Tingkat Dasar (KTD). Adapun materi yang disampaikan dalam kegiatan tersebut adalah sebagai berikut:

1. Pekan Penerimaan Anggota Baru (PPAB) yang berisikan materi keGMNI-an, materi Nasionalisme dan Patriotisme Indonesia, serta materi Peran Pemuda dan Mahasiswa dalam kehidupan bermasyarakat, berbangsa, dan bernegara. Diselenggarakan selama paling lama dua hari, dengan tujuan membangun intuisi kesadaran para calon anggota dan menjadikan Gerakan Mahasiswa Nasional Indonesia sebagai wadah dalam upaya mengimplementasikan tugas dan tanggung jawabnya dalam membangun kehidupan bermasyarakat, berbangsa dan bernegara.

2. Kaderisasi Tingkat Dasar (KTD) berisikan Metode Berpikir Marhaenisme,
Nasionalisme Indonesia, Sosiologi dan Analisa Sosial, Keorganisasian, Konstalasi Politik Nasional, dan KeGMNI-an. Disamping materi pokok, dalam Kaderisasi Tingkat Dasar juga akan diberi materi pendukung yakni materi-materi lokal yang disesuaikan dengan geografis dan geopolitik di tiap-tiap daerah. Materi lainnya adalah materi tentang dinamika kelompok dan dinamika pergerakan.

Sedangkan program kerja tambahan diluarprogram kerja wajibBidang Kaderisasi Dewan Pimpinan Komisariat Gerakan Mahasiswa Nasional Indonesia Universistas Muhammadiyah Malang mengacu kepada visi dan misi periode kepengurusan 20182019 yang ditransformasikan dengan cara melaksanakan diskusi rutin mingguan mengenai ideologi tentang Marhaenisme dan Pancasila 1 Juni ajaran Bung Karno, keorganisasian, serta memperkenalkan biografi tokoh bangsa yakni Bung Karno dengan pemateri dari dalam maupun luar serta alumni Gerakan Mahasiswa Nasional Indonesia.

\section{Sanksi Yang Dilakukan Oleh Gerakan Mahasiswa Nasional Indonesia Dalam Mentransformasikan Nilai-Nilai Pancasila Di Universitas Muhammadiyah Malang}

Peristilahan yang terakhir untuk pemilihan konsep perilaku kumpulan orang dalam teori peran menurut Biddle dan Thomas (dalam Suhardono, 1994) adalah sanksi. Sanksi adalah suatu perilaku dipertimbangkan sebagai "sanksi", kalau melalui perilaku tersebut tersirat niat untuk menimbulkan perubahan pada perilaku lainnya. Arah dari perubahan yang diinginkan, pada umumnya, tertuju pada naiknya konformitas terhadap suatu patokan yang di canangkan. Dalam konteks yang sama, sering disertakan istilahistilah, seperti "hukuman", "rangsangan" (incentive) dan "motivasi”, kalau dihadirkan 
secara tertutup, sanksi tersebut disebut "sanksi tak kasat mata" (convert sanction), sedang kalau terbuka disebut sebagai "sanksi kasat mata" (overt sanction). Sanksi juga mempunyai konotasi positifnegatif, tergantung pada apakah hal itu ditujukan pada perilaku yang diharapkan atau tidak diharapkan.

Dalam pelaksanaan setiap program kaderisasi yang diselenggarakan oleh Dewan Pimpinan Komisariat Gerakan Mahasiswa Nasional Indonesia Universitas Muhammadiyah Malang memberlakukan sanksi apabila kader yang telah mengikuti Pekan Penerimaan Angota Baru (PPAB) tidak mengikuti kajian rutin berupa Marhaenisme, Pancasila 1 Juni ajaran Bung Karno, keorganisasian, serta biografi tokoh bangsa yakni Bung Karno maka tidak diperbolehkan untuk mengikuti program kaderisasi yang selanjutnya, yakni Kaderisasi Tingkat Dasar. Hal tersebut bertujuan agar para kader terangsang dan termotivasi untuk turut aktif dalam setiap program kerja yang diselenggarakan oleh para pengurus Dewan Pimpinan Komisariat Gerakan Mahasiswa Nasional Indonesia Universitas Muhammadiyah Malang, dan masuk kedalam "sanksi kasat mata" (overt sanction) karena telah disosialisasikan terlebih dahulu kepada para kader yang bersifat terbuka.

Setiap proses kaderisasi yang dilakukan oleh Dewan Pimpinan Komisariat Gerakan Mahasiswa Nasional Indonesia Univeristas Muhammadiyah Malang kepada para anggotanya, menurut Kartono (2009) merupakan upaya edukatif yang intensional, disengaja, dan sistematis untuk membentuk individu sadar politik, dan mampu menjadi pelaku politik yang bertanggung jawab secara etis/moril mencapai tujuan-tujuan politik yang ingin dicapainya. Dengan tujuan menurut Amril (dalam Sunatra, 2016) melatih orang muda dan orang dewasa menjadi warga negara yang baik, khususnya dalam fungsi sosial dan fungsi politik. Membangkitkan dan mengembangkan hati nurani politik, rasa etika politik, dan tanggung jawab politik agar orang menjadi insan politik yang terpuji. Agar orang memiliki wawasan kritis mengenai relasi-relasi politik yang ada disekitarnya. Berpartisipasi politik dengan jalan memberikan pertimbangan yang konstruktif mengenai masyarakat dan kejadian politik itu merupakan hak-hak demokratis yang asasi. artisipasi aktif itu memiliki pengaruh dan kekuatan, sebab biasanya ikut pula dalam pengawasan aktivitas mengatur masyarakat dan negara.

Dari hasil temuan dilapangan meskipun Dewan Pimpinan Komisariat Gerakan Mahasiswa Nasional Indonesia Univeristas Muhammadiyah Malang dengan jelas menyebutkan Marhaenisme sebagai azas perjuangan organisasi, sebagai mana termaktub didalam Anggaran Dasar/Anggaran Rumah Tangga Gerakan Mahasiswa Nasional. Namun para pengurus menyadari, mengetahui, serta memaknai Marhaenisme dengan istilah "Marhaenisme is Pancasila, Pancasila is Marhaenisme". Hal ini karena dalam kajian dan proses kaderisasi yang dilakukan oleh Dewan Pimpinan Komisariat Gerakan Mahasiswa Nasional Indonesia Univeristas Muhammadiyah Malang secara turun-temurun memaparkan Marhaenisme merupakan titik awal munculnya ideologi negara yakni Pancasila.

DewanPimpinan KomisariatGerakan Mahasiswa Nasional Indonesia Univeristas Muhammadiyah Malang memahami bahwasanya Marhaenisme selain sebuah ideologi perjuangan, juga sebagai bagian dari sejarah yang tidak dapat dimaknai secara sepenggal-sepenggal. Para pengurus mempelajari secara akademik dalam bentuk bedah buku dan kajian rutinan mengenai hubungan Marhaenisme dan Pancasila sebagai ideologi negara dengan sangat rinci dan menggunakan litelatur-litelatur yang relevan. Penguasaan materi sejarah mengenai Marhaenisme para pengurus 
lakukan dengan membaca buku Dibawah Bendera Revolusi karangan Ir. Sukarno, selanjutnya para pengurus mempelajari materi Pancasila 1 Juni melalui litelatur buku "Lahirnya Pancasila" yang merupakan pidato Ir. Sukarno dihadapan Badan Penyelidik Usaha Persiapan Kemerdekaan Indonesia, selanjutnya Panitia Sembilan dan 18 Agustus 1945 disahkannya Pancasila sebagai Ideologi Negara merupakan materi wajib yang harus di kuasai oleh setiap pengurus sebelum melakukan kaderisasi kepada para anggotanya.

Agus (2016) menjelaskan bahwa Pancasila sebagai ideologi memiliki sifat yang terbuka. Hal ini berarti Pancasila dapat menerima dan mengembangkan pemikiran baru dari luar dan dapat berinteraksi dengan perkembangan/ perubahan zaman dan lingkungannya, bersifat demokratis dalam arti membuka diri masuknya budaya luar dan dapat menampung pengaruh nilainilai dari luar yang akan di inkorporasi, untuk memperkaya aneka bentuk dan ragam kehidupan bermasyarakat Indonesia juga memuat dimensi-dimensi secara menyeluruh.

Dalam mentransformasikan nilainilai Pancasila Dewan Pimpinan Komisariat Gerakan Mahasiswa Nasional Indonesia Univeristas Muhammadiyah Malang berpandu kepada ideologi Organisasi, yang menurut Notonagoro (1975) dasar ontologis dari ideologi pada hakekatnya adalah manusia. Karena manusia lah yang memiliki hakekat mutlak monopluralis, hakekat dasar ini juga disebut sebagai dasar antropologis. Subjek pendukung pokok-pokok Pancasila tersebut adalah manusia itu sendiri. Demikian juga jika kita pahami dari segi filsafat negara bahwa Pancasila sebagai dasar filsafat negara memiliki pendukung pokok negara yang tak lain adalah rakyat dan unsur rakyat adalah manusia itu sendiri.

Ketika para pengurus telah memaknai ideologi organisasi merupakan bagian dari ideologi negara yakni Pancasila sebagai pandangan hidup dalam kehidupan bermasyarakat, berbangsa, dan bernegara maka para pengurus dapat dikatakan sebagai pendukung pokok ideologi Pancasila. Dimana para pengurus Dewan Pimpinan Komisariat Gerakan Mahasiswa Nasional Indonesia Univeristas Muhammadiyah sebagai manusia yang berserikat didalam organisasi merupakan subyek pendukung dari sebuah ideologi yang berupaya mentransformasikan nilai-nilai Pancasila kedalam program kerja disetiap periode kepengurusan organisasi Gerakan Mahasiswa Nasional Indonesia.

Memalui program kerja yang diselengarakannya dengan misi melakukan ideologisasi secara terstruktur, masif, dan sistematif serta membangun doktrinasi ideologis secara berkelanjutan dan berkesinambungan dalam setiap kegiatan diskusi kader sebagaimana visi dari Dewan Pimpinan Komisariat Gerakan Mahasiswa Nasional Indonesia Univeristas Muhammadiyah periode kepengurusan 2018-2019 yakni memperjuangkan kembali DPK GMNI UMM sebagai lokomotif Gerakan Mahasiswa yang menjunjung tinggi ideologi Marhaenisme.

Maka program kerja yang di selenggarakan oleh Dewan Pimpinan Komisariat Gerakan Mahasiswa Nasional Indonesia Univeristas Muhammadiyah Malang menurut Good (1959) organisasi mahasiswa dapat menjadi "...a branch of study of the civics that emphasizes the individual's relation to his social enviroment which is conveived as a series of succesively enlarged communities, local, states, and nations". Lebih lanjut Winataputra (2012) menjelaskan organisasi mahasiswa dapat menjadi "Community Civic Education" didalamnya terdapat program dan/ atau proses pendidikan nonformal atau pendidikan in-formal yang dirancang dan/atau berlangsung dalam masing-masing jenis community dalam 
masyarakat bangsa dan negara (nationsstate community).

Pemaknaan atas hubungan ideologi organisasi dengan ideologi negara yang kemudian ditransformasikan melalui program kaderisasi sebagai upaya pendidikan politik yang dilakukan oleh Dewan Pimpinan Komisariat Gerakan Mahasiswa Nasional Indonesia Univeristas Muhammadiyah Malang adalah peranan nyata dalam dimensi fleksibilitas ideologi. Alfian (1991) untuk melihat keberhasilan pendidikan politik dapat ditentukan dengan suatu perspektif dua dimensi, dimensi pertama ialah berupa gambaran yang jelas tentang sistem politik ideal yang diinginkan, dimensi kedua ialah berupa realitas atau keadaan sebenarnya dari masyarakat itu sendiri yang langsung bisa dibandingkan dengan tuntutan-tuntutan sistem politik yang diinginkan secara ideal tadi.

Lebih lanjut dalam pemahaman dan pemaknaan Dewan Pimpinan Komisariat Gerakan Mahasiswa Nasional Indonesia Univeristas Muhammadiyah Malang terhadap hubungan ideologi organisasi dengan Pancasila menyadari terdapatnya hubungan antara Marhaenisme sebagai Azas perjuangan organisasi dan Pancasila 1 Juni ajaran Bung Karno sebagai ideologi organisasi dengan Pancasila sebagai ideologi Negara Republik Indonesia. Isi Marhaenisme tidak jauh berbeda dengan Pancasila 1 Juni kemudian di tarik lagi ke Pancasila 18 Agustus, dasarnya akan sama dan satu garis. Marhaenisme itu Sosio-nasionalisme dan Sosio-demokrasi serta Ketuhanan yang berkebudayaan, lalu Pancasila 1 Juni Bung Karno jelaskan dapat diperas menjadi menjadi trisila yakni Sosio-Nasionalisme, Sosio-Demokrasi, dan ketuhanan yang berkebudayaan yang merupakan isi dari Marhaenisme. Jadi secara keseluruhan, kesemuanya itu masih dalam satu kesatuan yang dapat ditarik garis yang sama.

Hal ini menurut (Alfian, 1986a) karena Pancasila sebagai ideologi mengandung tiga dimensi penting dalam dirinya, sehingga Pancasila sebagai ideologi dapat memelihara relevansinya yang tinggi/ kuat terhadap perkembangan aspirasi masyarakatnya dan tuntutan perubahan zaman. Ketiga dimensi yang terkandung dalam ideologi tersebut harus dapat saling berkaitan, saling mengisi, dan saling memperkuat sehingga menjadikan ideologi tersebut kenyal dan tahan uji dari masa kemasa. Ketiga dimensi itu adalah: 1) Dimensi Realita, 2) Dimensi Idealisme, 3) Dimensi Fleksibeitas.

Dimensi idealisme maksudnya adalah suatu ideologi perlu mengandung cita-cita yang ingin dicapai dalam berbagai bidang kehidupan bermasyarakat, berbangsa dan bernegara. Melalui idealisme atau citacita yang terkandung dalam ideologi yang dihayati suatu masyarakat atau bangsa mengetahui ke arah mana mereka ingin membangun kehidupan bersama mereka. Idealisme atau cita-cita tersebut seyogyanya berisi harapan-harapan yang masuk akal, bukanlah lambungan angan-angan yang sama sekali tidak mungkin direalisasikan.

Oleh karena itu dalam suatu ideologi yang tangguh biasanya terjalin perkaitan yang saling mengisi dan saling memperkuat antara dimensi realita dan dimensi idealisme yang terkandung di dalamnya. Dengan begitu ideologi tersebut akan berhasil menjadikan dirinya sebagai landasan atau dasar (melalui dimensi realita) dan sekaligus tujuan (melalui dimensi idealisme) dalam membangun berbagai bidang kehidupan bermasyarakat, berbangsa dan bernegara. Pemahaman dan penghayatan kita tentang Pancasila sebagai ideologi memang mengandung hal yang demikian itu, yaitu sebagai ideologi yang melandasi dan sekaligus menjadi tujuan kehidupan bersama kita. Logikanya, Pancasila bukan saja memenuhi dimensi kedua dari suatu ideologi, tetapi sekaligus juga memenuhi sifat berkaitan yang saling mengisi dan saling memperkuat antara dimensi pertama (dimensi realita) dengan dimensi ketiga 
(dimensi idealisme).

Dimensi realita maksudnya ideologi itu mengandung makna bahwa nilai-nilai dasar yang terkandung di dalam dirinya bersumber dari nilai-nilai yang riil hidup di dalam masyarakatnya, terutama pada waktu ideologi tersebut lahir, sehingga mereka betul-betul merasakan dan menghayati bahwa nilai-nilai dasar itu adalah milik mereka bersama. Dengan begitu nilai-nilai dasar ideologi itu tertanam dan berakar di dalam masyarakatnya. Menurut pandangan Alfian Pancasila mengandung dimensi realita ini di dalam dirinya.

Dimensi fleksibilitas atau dimensi pengembangan hanya mungkin dimiliki secara wajar dan sehat oleh suatu ideologi yang terbuka atau ideologi yang demokratis. Hal tersebut karena ideologi yang terbuka atau demokratis justru menemukan, meletakkan atau bahkan mempertaruhkan relevansi atau kekuatannya pada keberhasilannya merangsang masyarakatnya untuk mengembangkan pemikiran-pemikiran baru tentang nilai-nilai dasar yang terkandung di dalamnya. Melalui pemikiran-pemikiran baru tentang ideologi itu mempersegar dirinya, memelihara dan memperkuat relevansinya dari waktu ke waktu. Dari situ kita barang kali dapat menyimpulkan bahwa suatu ideologi terbuka, karena bersifat demokratis, memiliki apa yang mungkin dapat kita sebut sebagai dinamika internal yang mengundang dan merangsang mereka yang meyakininya untk mengembangkan pemikiran-pemikiran baru tentang dirinya tanpa khawatir atau menaruh curiga akan kehilangan hakekat dirinya.

Oleh karena itu demokrasi menjadi pilihan dibanyak negara, didalam konsep demokrasi terdapat banyak aspek partisipasi yang sangat dibutuhkan dalam pembangunan. Pembangunan dewasa ini lebih dipusatkan kepada manusia (people centered), model pembangunan yang berpusat kepada manusia ini bertujuan agar terpenuhinya kebutuhan dasar masyarakat. Tetapi yang lebih penting adalah upaya apa yang dilakukan agar kuliatitas manusia itu menjadi meningkat, sehingga partisipasi secara nyata dalam berbagai aktifitas kehidupan mendorong terciptanya kegiatan yang produktif dan bernilai tinggi untuk masyarakat itu sendiri (Witianti, 2016).

\section{SIMPULAN}

Peran organisasi Dewan Pimpinan Komisariat Gerakan Mahasiswa Nasional Indonesia Universitas Muhammadiyah Malang dalam mentrasformasikan nilai-nilai Pancasila dilakukan dengan bentuk Program Kerja disetiap periode kepengurusan organisasi. DPK GMNI UMM dipimpin oleh Komisaris yang bertanggung jawab atas semua program kerja yang dilaksanakannya dalam satu periode kepengurusan. Dalam kepengurusan tersebut terdapat berbagai macam bidang yang bertanggung jawab terhadap Komisaris dalam melaksanakan program kerja organisasi. Setiap program kerja yang diselenggarakan diikuti oleh anggota atau terbuka untuk umum.

Adapun program kerja yang telah dilaksanakan oleh Dewan Pimpinan Komisariat Gerakan Mahasiswa Nasional Indonesia Universitas Muhammadiyah Malang pada masa kepengurusan 20182019 diantaranya adalah Pekan Penerimaan Anggota Baru, Kaderisasi Tingkat Dasar, diskusi rutin mingguan mengenai ideologi tentang Marhaenisme dan Pancasila 1 Juni ajaran Bung Karno, keorganisasian, serta memperkenalkan biografi tokoh bangsa yakni Bung Karno, kajian dan diskusi di hari-hari besar dengan mengundang organisasi eksternal dan organisasi internal kampus, penyikapan terhadap isu-isu kontemporer yang berkembang didalam kampus maupun luar kampus, serta yang terakhir silaturahmi antar anggota dan alumni Dewan Pimpinan Komisariat Gerakan Mahasiswa Nasional Indonesia Universitas Muhammadiyah Malang yang diselenggarakan setahun sekali. 
Dewan Pimpinan Komisariat Gerakan Mahasiswa Nasional Indonesia Univeristas Muhammadiyah Malang dengan jelas menyebutkan Marhaenisme sebagai azas perjuangan organisasi, sebagaimana termaktub didalam Anggaran Dasar/ Anggaran Rumah Tangga Gerakan Mahasiswa Nasional. Namun para pengurus menyadari, mengetahui, serta memaknai Marhaenisme dengan istilah "Marhaenisme is Pancasila, Pancasila is Marhaenisme". Hal ini karena dalam kajian dan proses kaderisasi yang dilakukan oleh Dewan Pimpinan Komisariat Gerakan Mahasiswa Nasional Indonesia Univeristas Muhammadiyah Malang secara turuntemurun memaparkan Marhaenisme merupakan titik awal munculnya ideologi negara yakni Pancasila.

Pemahaman dan pemaknaan Dewan Pimpinan Komisariat Gerakan Mahasiswa Nasional Indonesia Univeristas Muhammadiyah Malang terhadap hubungan ideologi organisasi dengan Pancasila menyadari terdapatnya hubungan antara Marhaenisme sebagai Azas perjuangan organisasi dan Pancasila 1 Juni ajaran Bung Karno sebagai ideologi organisasi dengan Pancasila sebagai ideologi Negara Republik Indonesia. Isi Marhaenisme tidak jauh berbeda dengan Pancasila 1 Juni kemudian di tarik lagi ke Pancasila 18 Agustus, dasarnya akan sama dan satu garis. Marhaenisme itu Sosio-nasionalisme dan Sosio-demokrasi serta Ketuhanan yang berkebudayaan, lalu Pancasila 1 Juni Bung Karno jelaskan dapat diperas menjadi menjadi trisila yakni Sosio-Nasionalisme, Sosio-Demokrasi, dan ketuhanan yang berkebudayaan yang merupakan isi dari Marhaenisme. Jadi secara keseluruhan, kesemuanya itu masih dalam satu kesatuan yang dapat ditarik garis yang sama.

\section{DAFTAR PUSTAKA}

Agus, A, A. (2016). Relevansi Pancasila Sebagai Ideologi Terbuka Di Era Reformasi. Jurnal Office, 2(2),
229-238. https://doi.org/https://doi. org/10.26858/jo.v2i2.2958

Akbar, I. (2016). Demokrasi Dan Gerakan Sosial (Bagaimana Gerakan Mahasiswa Terhadap Dinamika Perubahan Sosial). Jurnal Wacana Politik. https://doi. org/10.24198/jwp.v1i2.11052

Alfian. (1986a). Masalah dan Prospek Pembangunan Politik Indonesia Kumpulan Karangan. Gramedia Pustaka Utama.

Alfian. (1986b). Pemikiran Dan Perubahan PolitikIndonesia Kumpulan Karangan. Gramedia Pustaka Utama.

Alfian. (1991). Pancasila Sebagai Ideologi Dalam Kehidupan Politik. In Pancasila sebagai Ideologi Dalam Berbagai Bidang Kehidupan Bermasyarakat, Berbangsa Dan Bernegara. BP-7 Pusat.

Ali, A. S. (2009). Negara Pancasila: jalan kemaslahatan berbangsa. Pustaka LP3ES.

CNN Indonesia. (2019). Cyrus: Hanya 70 persen Responden Muslim Setuju Pancasila. https://www.cnnindonesia.com/nasional/ 20190809164210-20-419916/cyrushanya-70-persen-responden-muslimsetuju-pancasila

Good, C. V. (1959). Dictionary of Education. M. Graw Hiil Book Conpanny.

Hidayat,F.(2018). Survei LSI: Pro-Pancasila Turun 10\%, Pro-NKRI Bersyariah Naik 9\%. Www.Detik.Com. https:// news.detik.com/berita/d-4119173/ survei-1si-pro-pancasila-turun-10pro-nkri-bersyariah-naik-9

Kartono, K. (2009). Pendidikan Politik Sebagai Bagian Dari Pendidikan Orang Dewasa. Mandar Maju.

Kongres Trisaksi GMNI Ke-XX. (2017). Anggaran Dasar dan Anggaran Rumah Tangga Gerakan Mahasiswa Nasional Indonesia Periode 20172019. Dewan Pimpinan Pusat Gerakan Mahasiswa Nasional Indonesia. 
Manan, B., \& Harijanti, S. D. (2014). Artikel Kehormatan: Saat Rakyat Bicara: Demokrasi dan Kesejahteraan. Pandjadjaran Jurnal Ilmu Hukum, 1(1), 1-18. https://doi.org/https:// doi.org/10.22304/pjih.v1n1.a1

Notonagoro. (1975). Pancasila Secara Ilmiah Populer. Pantjuran Tudjuh.

Pratama, Y., Suntoro, I., \& Yunisca, N. (2018). Peranan Organisasi Gerakan Mahasiswa Nasional Indonesia (GMNI) Dalam Meningkatkan Sikap Nasionalisme. Jurnal Kultur Demokrasi, 5(13), 1-14.

Saputro, Y. D. (2015). Peran Partai Politik Dalam Pendidikan Politik Generasi Muda Dan Implikasinya Terhadap Ketahanan Politik Wilayah (Studi Di DPD II Partai Golongan Karya Kota Malang Jawa Timur Tahun 2009 2014). Jurnal Ketahanan Nasional, XXI(1), 34-42. https://doi.org/ https://doi.org/10.22146/jkn.6892

Siregar, E. (2012). Toleransi di Bumi Pancasila. In Editorial Majelis Edisi No. 06/ Th. VI/ Juni 2012. MPR-RI.

Suhardono, E. (1994). Teori Peran Konsep, Derivasi dan Implikasinya. Gramedia Pustaka Utama.

Sunatra. (2016). Pendidikan Politik Kewarganegaraan. LEKKAS.

Taniredja, T. (2014). Prosiding Kongres Pancasila VI: Penguatan, sinkronisasi, harmonisassi, integrasi pelembagaan dan pembudayaan Pancasila dalam rangka memperkokoh kedaulatan bangsa. In Pusat Studi Pancasila UGM (Ed.), Konsensus Kebangsaan (Pancasila Dan Undang-Undang Dasar Negara Republik Indonesia Tahun 1945) (pp. 438-453). Pusat Studi Pancasila UGM.

Wibowo, A. P. (2020). The Efforts Of Demokrasi Indonesia Perjuangan Party Regional Board Struggle In Transformation Pancasila Values On Cadre. Jurnal Ilmiah Pendidikan
Pancasila Dan Kewarganegaraan, 5(1), 33-41. http://journal2. um.ac.id/index.php/jppk/article/ view/12673/6096

Wibowo, A. P., Sumantri, E., \& Syaifullah. (2016). Transformasi Nilai-Nilai Pancasila Melalui Organisasi Mahasiswa Guna Meningkat Kesadaran Berbangsa Dan Bernegara (Studi Deskriptif Terhadap Organisasi Mahasiswa Jurusan Di Fakultas Pendidikan Ilmu Pengetahuan Sosial, Universitas Pendidikan Indonesia). Proceeding Internasional Seminar Pendidikan Kewarganegaraan Sebagai Bidang Keilmuan Dan Program Pendidikan Dalam Konteks Penguatan Daya Saing Lulusan, 400-411.

Wibowo, A. P., \& Wahono, M. (2017). Pendidikan Kewarganegaraan: usaha konkret memperkuat multikulturalisme di Indonesia. Jurnal Civics: Media Kajian Kewarganegaraan, 14(2), 196-205. https://doi.org/10.21831/civics. v14i2.16043

Winataputra, U. S. (2012). Pendidikan kewarganegaraan dalam perspektif pendidikan untuk mencerdaskan kehidupan bangsa: gagasan, instrumentasi, dan praksis. Widya Aksara Press.

Witianti, S. (2016). Demokrasi Dan Pembangunan. Jurnal Wacana Politik, 1(1), 71-76. https://doi.org/https:// doi.org/10.24198/jwp.v1i1.10547

Zamroni. (1990). Peran organisasi Mahasiswa Dalam Pembangunan. Jurnal Bestari, 5(1), 66-71. http:// ejournal.umm.ac.id/index.php/ bestari/article/view/3045/3699 
